\title{
Investigation of seed germination indices for early selection of salinity tolerant genotypes: A case study in wheat
}

\author{
Fatemeh Aflaki ${ }^{1,2}$, Mohammad Sedghi ${ }^{3}$, Arman Pazuki ${ }^{1,2}$, Mohammad Pessarakli* ${ }^{4 *}$ \\ ${ }^{1}$ Abant Izzet Baysal University, Department of Biology, 14280 Bolu, Turkey, ${ }^{2}$ Sugar Institute, Plant Breeding Department, 06930 Etimesgut, \\ Ankara, Turkey, ${ }^{3}$ University of Mohaghegh Ardabili, Faculty of Agricultural Sciences, Department of Agronomy and Plant Breeding, Ardabil, \\ Iran, ${ }^{4}$ School of Plant Sciences, College of Agriculture and Life Sciences, The University of Arizona, Tucson, Arizona 85721, USA
}

\section{A B S T R A C T}

\begin{abstract}
Plant establishment is highly correlated with successful germination and seedling growth, the most sensitive and critical stages. Abiotic stresses by their limiting and adverse effects on these stages finally result in poor yield. Therefore, investigating resistance to salinity among genotypes of a desired plant is highly recommended for anticipated drought seasons. To study the effects of salinity on seed germination and initial growth of seedlings, a factorial experiment was conducted based on a completely randomized design with four replicates using three wheat (Triticum aestivum) genotypes (Zagros, Gascogen and Kuhdasht). Salinity levels included 0 (control), 3.5 , and $7 \mathrm{dS} \mathrm{m}^{-1}$ (deci-Siemens per meter). The results indicated that salinity had a significant influence on different germination indices ( $P$ $<0.05)$. In all the genotypes, with an increase in salinity levels, indices including germination percentage, germination rate, seed vigor, coefficient of germination rate, coleoptile to plumule ratio, and daily germination mean decreased. Unlike the mentioned indices, the ratio of the radicle to plumule and the mean of germination time increased. Zagros genotype showed more tolerant than the other two. Based on these results, it seems that germination indices may be effectively used in selecting tolerant plants to salinity stress.
\end{abstract}

Keywords: Germination indices; Salinity tolerance; Seed vigor; Triticum aestivum; Wheat

\section{INTRODUCTION}

About $3.4 \%$ of the world soils are salt-affected, which consists of 397 million ha saline soils and 434 million ha sodic and saline sodic soils throughout the world. It has been estimated about $19.5 \%$ of irrigated land (45 million ha) are salt-affected (FAO soils portal). In addition, irrigation per se can exacerbate soil salinization (Smedema and Shiati, 2002).

Salinity is globally one of the most formidable barriers against plant production and crop yield. In addition, as a limiting factor, salinity stress can adversely affect normal plant establishment (Houle et al., 2001; Pessarakli et al., 2015), reduce plant growth and development (Panuccio et al., 2014; Izadi et al., 2014; Pessarakli, 2015; Pakar et al., 2016), stunt plant growth and survival (Parida et al., 2005; Akhzari et al., 2016) in different ways, e.g., photosynthesis, nutritional condition, metabolism, drought stress, oxidative stress, membrane damage, and limited cell division (Aflaki Manjili et al., 2012; Houle et al., 2001; Panuccio et al., 2014). However, osmotic and ionic toxicity are more harmful than aforementioned factors (Panuccio et al., 2014).

Seed germination is the initial step in plant life, where it has an influential role in yield (Houle et al., 2001; Sanchez et al., 2014). Salinity generally delays or prevents seed germination and seedling establishment. Reduction of germination in saline soils mostly is aggravated by movement of saline solution to soil surface due to evaporation. Germination and plantlet growth indices (e.g., percentage and vigor) are two of the most important criteria for selection of tolerant cultivars (Bybordi, 2009). Stress time is a determining factor in selection stage. Since wheat seedlings are more sensitive to salinity during germination than during emergence and early seedling growth (Francois et al., 1986), if screening for the tolerant ones be done after germination, the screening may not be helpful in finding tolerant genotypes (Feyzi, 2003).

\footnotetext{
${ }^{*}$ Corresponding author:

Mohammad Pessarakli. School of Plant Sciences, College of Agriculture and Life Sciences, The University of Arizona, Tucson, Arizona 85721, USA. E-mail: pessarak@email.arizona.edu
} 
Based on the previous research, salinity can decrease germination percentage (Houle et al., 2001; Sanchez et al., 2014), germination rate (Hadas, 1977; Sanchez et al., 2014), and the mean germination time (Jeannette et al., 2002). Salinity effects on plant metabolism can limit crop yield (Ayaz et al., 2000; Pakar, 2016), or in worse cases, high salinity level could fully suppress germination (Houle et al., 2001; Sanchez et al., 2014).

The latest FAO Statistics shows that wheat was the fourth large-scale crop production among top-five cereals produced in 2013. Although there has recently been a shift in crop production, wheat still serves as one of the primary sources of food for human consumption (FAO, 2015).

Nearly all of the main crops, including wheat, are generally classified as glycophyte, whose life processes are sensitive to salinity. However, the response of different genotypes may differ.

Therefore, it is worthwhile considering the problems caused by salinity in production of this strategic crop, and it is potentially rewarding to seek for salinity resistant plants. Previously, we had investigated the effects of salinity on mature wheat, where we recorded some physiological parameters for the most tolerant and susceptible genotypes to the stress (Aflaki Manjili et al., 2012; Pazuki et al., 2013). In the present research, we have studied effects of the same levels of salinity on the previously used three wheat genotypes affected by two levels of salinity in comparison with distilled water (control). The key aim was to examine the possibility of effectively and quickly deploying seed germination indices and germinated seedling growth parameters for screening resistant genotypes/seedlings against salinity for early selection of the tolerant genotypes at seed germination stage rather than later stages of maturity when plant is about to yield.

\section{MATERIALS AND METHODS}

\section{Plant materials and treatments}

Seeds of three wheat (Triticum aestivum) genotypes (Zagros, Gascogen and Kuhdasht) were subjected to three salinity levels $\left(0,3.5\right.$, and $\left.7 \mathrm{dS} \mathrm{m}^{-1}\right)$ with four replicates in a factorial experiment based on a completely randomized design. The seeds were sterilized by sodium hypochlorite $0.5 \%$ for 3 minutes, and after three times rinsing with distilled water, 25 seeds were selected for each replicate. These seeds were placed on a filter paper in $9 \mathrm{~cm}$ Petri dishes. Then, saline solutions were prepared by dissolving sodium chloride $(\mathrm{NaCl})$ in $7 \mathrm{ml}$ distilled water, which was poured into each Petri dish. For the control, $7 \mathrm{ml}$ distilled water was used. After sealing the Petri dishes with parafilm, they were kept in a growth chamber at $24 \pm 1^{\circ} \mathrm{C}$, relative humidity of $80 \pm 3 \%$, irradiated under $50 \mu \mathrm{mol} \mathrm{m}^{-2} \mathrm{~s}^{-1}$ with an 18 -h photoperiod.

\section{Experimental design and analysis}

The germinated seeds were counted from the second day to the eighth day. On the ninth day, seedlings were measured for the length of roots, stems, and coleoptile. Means of the observations recorded for the indices were compared after confirming data normality, through variance analysis using Duncan's multiple range test (Duncan, 1955).

\section{Formula of the indices}

Germination percentage and germination rate:

1. $\mathrm{GR}=\sum_{\mathrm{i}=1}^{\mathrm{n}} \mathrm{Si} / \mathrm{Di}$

In this formula, GR is germination rate; $\mathrm{Si}$ is germinated seeds per counting, Di represents seed numbers until $\mathrm{n}^{\text {th }}$ day, and $\mathrm{n}$ is number of the countings (Maguire, 1962).

\section{Seed vigor and daily germination mean:}

2. $\mathrm{MDG}=\frac{F G P}{d}$

MDG is daily germination mean, FGP stands for final germination percentage, and $\mathrm{d}$ represents number of days (Scott et al., 1984).

\section{Coefficient of germination rate:}

3. $\mathrm{CVG}=\frac{G 1+G 2+\ldots+G \mathrm{n}}{(1 \times G 1)+(2 \times G 2)+\ldots+(\mathrm{n} \times G \mathrm{n})}$

CVG is coefficient of germination rate, and G1-Gn is the number of germinated seeds from the first to the last day (Maguire, 1962).

Germination stress index:

4. $G S I=\frac{P I S}{P I C} * 100$

$\mathrm{PI}=\mathrm{nd} 2(1)+\mathrm{nd} 3(0.9)+\mathrm{nd} 4(0.8)+\mathrm{nd} 5(0.7)+\mathrm{nd} 6(0.4)+$ $\operatorname{nd} 7(0.3)$

In this formula, nd2 until nd7 are germinated seeds from the first to the seventh day.

$\mathrm{GSI}=[\mathrm{PI}$, under stress condition/PI, under non-stress condition] (Bouslama and Schapaugh, 1984).

Mean of germination time:

5. $M T G=\frac{\Sigma(n d)}{n}$

Where, nd is number of germinated seeds in d days and $\sum \mathrm{n}$ number of total germinated seeds (Ellis and Roberts, 1981). 


\section{RESULTS AND DISCUSSION}

Based on the results of the present study, the genotype main effect on germination percentage was not significant. Salinity, however, showed a significant effect $(\mathrm{P}<0.05)$ on germination percentage (Table 1). Salinity level at $7 \mathrm{dS} \mathrm{m}^{-1}$ resulted in a significant reduction $(\mathrm{P}<0.05)$ in germination percentage when compared with the $3.5 \mathrm{dS} \mathrm{m}^{-1}$ and the control. It can be due to the salinity effect on water absorption, where salinity reduces osmotic potential and subsequently water potential, therefore limits water uptake by plants (Jeannette et al., 2002).

For germination rate, interaction of genotype and salinity was significant $(\mathrm{P}<0.05)$ (Table 1). The highest amount of germination rate was observed in the control for Zagros, while the lowest amount was recorded in the $7 \mathrm{dS} \mathrm{m}^{-1}$ treatment for Gascogen (Table 2). In saline condition, water required for germination is absorbed more slowly by seed than that under normal (non-saline) condition. Furthermore, increasing in phenolic compounds due to salinity may disturb metabolic processes (Ayaz et al., 2000). It is suggested that germination rate is decreased by these inhibitors and water movement is restricted (Hadas, 1977). The main cause of the decrease in both germination rate and percentage can be the excess of toxic cations and anions $\left(\mathrm{Na}^{+}\right.$and $\left.\mathrm{Cl}^{-}\right)$, which reduces water potential besides their toxicity in susceptible plants or genotypes (Houle et al., 2001; Sanchez et al., 2014). However, other research groups reported that various salts $\left(\mathrm{NaCl}, \mathrm{CaCl}_{2}\right.$, $\mathrm{KCl}$, and $\mathrm{MgCl}_{2}$ ) at lower concentrations have stimulatory effect on germination rate of a halophyte plant, but not on germination percentages (Panuccio et al., 2014), or depending on the ambient condition, germination rate of barley may increase. It is suggested that resistant plants to saline condition by having relatively higher germination rate may out-compete glycophyte competitors in saline soils. Germination may be accelerated by absorbing sodium ion to allow halophytes absorb more water (Zhang et al., 2010).

Genotype had a significant effect on the mean of germination time, whereas coefficient of germination rate was not affected by neither genotype nor salinity (Table 1).
The effect of genotype was not significant on the other variables, including seed vigor, daily germination mean, radicle to plumule ratio, and coleoptile to plumule ratio, but the effect of salinity was significant $(\mathrm{P}<0.05)$ on them (Table 1). Water movement limitation due to salinity up to $3.5 \mathrm{dS} \mathrm{m}^{-1}$ increased root growth, however, root growth was more restricted at $7 \mathrm{dS} \mathrm{m}^{-1}$. Similarly, seedling roots of a succulent shrub (Halocnemum strobilaceum) elongated more by low salinity, but an increase in salinity negatively affected them ( $\mathrm{Qu}$ et al., 2008). The genotypes that produce longer roots in high salinity are more resistant to salinity and yield higher than sensitive ones (Julkowska et al., 2014).

Daily germinations and seed vigor means were reduced by increase in salinity levels. Therefore, the highest amount of seed vigor was observed in the control (Table 3). Salinity of $3.5 \mathrm{dS} \mathrm{m}^{-1}$ significantly decreased coleoptile to plumule ratio $(\mathrm{P}<0.05)$ (Table 3$)$. Due to salinity and low amount of water, coleoptile as the first emerging part of the plant, grew more slowly than that under the control (non-saline condition).

Germination stress index showed a reduction by an increase in salinity, but it was not significant (data not shown). In other words, the number of germinated seeds under salinity stress did not decrease significantly. This was examined to determine salinity tolerance, which appeared potentially a beneficial index for selecting resistant genotypes.

Correlations between germination percentage, germination rate, mean of germination time, coefficient of germination rate, daily germination mean, seed vigor, radicle to plumule, and coleoptile to plumule were estimated (Table 4). The highest correlation was between daily germination mean and germination percentage $(\mathrm{r}=1)$, and the lowest positive correlation was between seed vigor and daily germination mean $(r=0.29)$. The higher seed vigor, the more germination per day.

Between the seed vigor and coleoptile to plumule ratio, a significant negative correlation was observed (-0.61). Due

Table 1: Variance analysis of salinity and genotype interaction on germination indices of wheat seeds

\begin{tabular}{|c|c|c|c|c|c|c|c|c|c|}
\hline \multirow[t]{2}{*}{ Variables } & \multirow[t]{2}{*}{ DF } & \multicolumn{8}{|c|}{ Mean of squares } \\
\hline & & $\begin{array}{l}\text { Germination } \\
\text { percentage (\%) }\end{array}$ & $\begin{array}{l}\text { Germination } \\
\text { rate }\end{array}$ & $\begin{array}{l}\text { Germination } \\
\text { time mean }\end{array}$ & $\begin{array}{c}\text { Coefficient of } \\
\text { germination } \\
\text { rate }\end{array}$ & $\begin{array}{c}\text { Daily } \\
\text { germination } \\
\text { mean }\end{array}$ & $\begin{array}{l}\text { Seed } \\
\text { vigor }\end{array}$ & $\begin{array}{c}\text { Radicle to } \\
\text { plumule } \\
\text { ratio }\end{array}$ & $\begin{array}{c}\text { Coleoptile } \\
\text { to plumule } \\
\text { ratio }\end{array}$ \\
\hline Genotype & 2 & $25.333^{\text {ns }}$ & $109.204^{\star \star}$ & $0.000^{\star *}$ & $2573.158^{\text {ns }}$ & $0.517^{\text {ns }}$ & $0.001^{\mathrm{ns}}$ & $3.053^{\text {ns }}$ & $134.814^{\mathrm{ns}}$ \\
\hline Salinity & 2 & $84.000^{*}$ & $54.916^{*}$ & $0.000^{\text {ns }}$ & $2932.492^{\text {ns }}$ & $1.715^{\star}$ & $0.003^{\star *}$ & $1391.502^{\star *}$ & $1584.764^{\star *}$ \\
\hline Interaction & 4 & $23.333^{\text {ns }}$ & $9.005^{*}$ & $0.000^{\text {ns }}$ & $1119.995^{\text {ns }}$ & $0.477^{\text {ns }}$ & $0.000^{\text {ns }}$ & $0.638^{\text {ns }}$ & $64.990^{\text {ns }}$ \\
\hline Error & 27 & 21.630 & 12.941 & 0.000 & 1148.290 & 0.441 & 0.000 & 1.818 & 53.554 \\
\hline $\begin{array}{l}\text { coefficient } \\
\text { of variation }\end{array}$ & & 4.98 & 6.28 & 7.45 & 5.37 & 4.98 & 20.41 & 6.13 & 5.28 \\
\hline
\end{tabular}


to salinity, root growth increases to find more fresh water (Julkowska et al., 2014), while shoot growth decreases because of ion toxicity by inhibiting photosynthesis among other processes (Munns, 2002).

The highest negative correlation was observed between the mean of the germination time and germination rate $(\mathrm{r}=-0.98)$, which was followed by correlation between coefficient of the germination rate and the mean of the germination time $(\mathrm{r}=-0.84)$.

Our previous publications support the results presented here. We observed that Zagros, the most tolerant genotype in the present report, had produced the highest amount of Rubisco, peroxidase and proline, and susceptible genotype (Gascogen) had accumulated the lowest amounts at $7 \mathrm{dS} \mathrm{m}^{-1}$ (Aflaki Manjili et al., 2012). In addition, we reported that Zagros contained more chlorophyll, showed more membrane stability, and had the least chlorophyll fluorescence. Comparison of tolerance to salinity stress across the genotypes with their corresponding control showed that Zagros had the least rate of decrease in

Table 2: Mean comparison of salinity and genotype interaction effect on germination rate of wheat seeds

\begin{tabular}{lccc}
\hline Salinity $\left(\mathrm{dS} \mathrm{m}^{-1}\right)$ & \multicolumn{3}{c}{ Germination rate (seeds per day) } \\
\cline { 2 - 4 } & Kuhdasht & Zagros & Gascogen \\
\hline Control $(0)$ & $59.66 \mathrm{abc}$ & $62.65 \mathrm{a}$ & $54.54 \mathrm{~cd}$ \\
3.5 & $56.74 \mathrm{bcd}$ & $61.85 \mathrm{ab}$ & $55.41 \mathrm{~cd}$ \\
7 & $55.44 \mathrm{~cd}$ & $56.34 \mathrm{bcd}$ & $52.80 \mathrm{~d}$ \\
\hline \multicolumn{2}{l}{ Similar letters are not significantly different at $1 \%$ probability level }
\end{tabular}

membrane stability at $7 \mathrm{dS} \mathrm{m}^{-1}$ salinity. Moreover, genotypes with higher tolerance had the highest stomatal conductance, which is an indicator for stress tolerance (Pazuki et al., 2013). In the present investigation, we observed that Zagros is the most tolerant genotype and Gascogen is the least tolerant one, which is in agreement with our previous publications.

\section{CONCLUSIONS}

Salinity as a global threat to plant production could halt or suppress seed germination and plant establishment mainly due to ionic and osmotic toxicity. However, responses of plants or genotypes to the same condition are not similar. Salinity effects in low and high levels on germination indices may be different. Tolerant genotypes screening can be done by evaluating germination indices under salinity condition. Therefore, germination indices can be considered an effective screening tool in the early stages of plant establishment. This idea is supported by our previous publications, which suggest that physiological traits of a plant at later stages may be surmised by evaluating germination indices.

\section{ACKNOWLEDGMENTS}

This research did not receive any specific grant from funding agencies in the public, commercial, or not-forprofit sectors.

Table 3: Mean comparison of salinity levels on studied traits in wheat genotypes

\begin{tabular}{lcccccc}
\hline Salinity (dS m-1) & $\begin{array}{c}\text { Germination } \\
\text { percentage (\%) }\end{array}$ & $\begin{array}{c}\text { Daily germination mean } \\
\text { (seeds per day) }\end{array}$ & Seed vigor & Radicle to plumule & Coleoptile to plumule \\
\hline Control (0) & $95.33 \mathrm{a}$ & $13.62 \mathrm{a}$ & $0.089 \mathrm{a}$ & $9.58 \mathrm{~b}$ & $151.5 \mathrm{a}$ \\
3.5 & $94.33 \mathrm{a}$ & $13.48 \mathrm{a}$ & $0.067 \mathrm{a}$ & $28.71 \mathrm{a}$ & $134.7 \mathrm{~b}$ \\
7 & $90.33 \mathrm{~b}$ & $12.90 \mathrm{~b}$ & $0.058 \mathrm{a}$ & $27.73 \mathrm{a}$ & $129.5 \mathrm{~b}$ \\
\hline
\end{tabular}

Similar letters are not significantly different at the $1 \%$ probability level

Table 4: Correlation amongst studied traits in wheat genotypes under salinity

\begin{tabular}{|c|c|c|c|c|c|c|c|c|}
\hline & $\begin{array}{c}\text { Germination } \\
\text { percentage }(\%)\end{array}$ & $\begin{array}{l}\text { Germination } \\
\text { rate }\end{array}$ & $\begin{array}{c}\text { Mean of } \\
\text { germination } \\
\text { time }\end{array}$ & $\begin{array}{c}\text { Coefficient } \\
\text { of } \\
\text { germination } \\
\text { rate }\end{array}$ & $\begin{array}{c}\text { Daily } \\
\text { germination } \\
\text { mean }\end{array}$ & $\begin{array}{l}\text { Seed } \\
\text { vigor }\end{array}$ & $\begin{array}{l}\text { Radicle to } \\
\text { plumule }\end{array}$ & $\begin{array}{l}\text { Coleoptile } \\
\text { to plumule }\end{array}$ \\
\hline $\begin{array}{l}\text { Germination } \\
\text { percentage (\%) }\end{array}$ & 1 & & & & & & & \\
\hline Germination rate & $0.745^{\star \star}$ & 1 & & & & & & \\
\hline $\begin{array}{l}\text { Mean of germination } \\
\text { time }\end{array}$ & $-0.711^{\star *}$ & $-0.981^{\star \star}$ & 1 & & & & & \\
\hline $\begin{array}{l}\text { Coefficient of } \\
\text { germination rate }\end{array}$ & $0.933^{\star *}$ & $0.873^{\star *}$ & $-0.842^{\star *}$ & 1 & & & & \\
\hline $\begin{array}{l}\text { Daily germination } \\
\text { mean }\end{array}$ & $1.000^{* *}$ & $0.745^{\star *}$ & $-0.711^{* *}$ & $0.933^{\star *}$ & 1 & & & \\
\hline Seed vigor & $0.294^{\text {ns }}$ & $0.141^{\text {ns }}$ & $-0.118^{\text {ns }}$ & $0.172^{\text {ns }}$ & $0.295^{\mathrm{ns}}$ & 1 & & \\
\hline Radicle to plumule & $-0.159^{\text {ns }}$ & $-0.145^{\mathrm{ns}}$ & $0.125^{\mathrm{ns}}$ & $-0.089^{n s}$ & $-0.160^{\mathrm{ns}}$ & $-0.609^{\star *}$ & 1 & \\
\hline Coleoptile to plumule & $0.789^{\star \star}$ & $0.743^{* *}$ & $-0.708^{* *}$ & $0.799^{\star *}$ & $0.789^{\star \star}$ & $0.514^{\star *}$ & $-0.670^{* *}$ & 1 \\
\hline
\end{tabular}

${ }^{n s}$ not significant. * ${ }^{* *}$ Significant at the $5 \%$ and $1 \%$ levels of probability according to Duncan Multiple range test 


\section{Author's contributions}

F.A. conducted the experiment, analyzed the results, discussed the results, and drafted the manuscript. M.S. supervised and designed the research. A.P. analyzed and discussed the results. M.P. advised and designed the research, and reviewed the manuscript.

\section{REFERENCES}

Aflaki Manjili, F. A., M. Sedghi and M. Pessarakli. 2012. Effects of phytohormones on proline content and antioxidant enzymes of various wheat cultivars under salinity stress. J. Plant Nutr. 35: 1098-1111.

Akhzari, D., M. Khedmati, A. Soleimani and M. Pessarakli. 2016. Growth, survival, protein content and phytoremediation potency of various rangeland plant species (Medicago polymorpha L., Medicago rigidula L. and Onobrychis sativa L.) Grown in vermicompost-containing potting media. Commun. Soil Sci. Plant Anal. J. 47(20): 2261-2270.

Ayaz, F. A., A. Kadioglu and R. Turgut. 2000. Water stress effects on the content of low molecular weight carbohydrates and phenolic acids in Ctenanthe setosa (Rosc.) Eichler. Can. J. Plant Sci. 80: 373-378.

Bouslama, M. and W. T. Schapaugh. 1984. Stress tolerance in soybeans. I. Evaluation of three screening techniques for heat and drought tolerance. Crop Sci. 24: 933-937.

Bybordi, A. 2010. The Influence of salt stress on seed germination, growth and yield of canola cultivars. Not. Bot. Hoti. Acrobot. Cluj. 38: 128-133.

Duncan, D. B. 1955. Multiple range and multiple F tests. Biometrics. 11: 1-42.

Ellis, R. H. and E. H. Roberts. 1981. The quantification of ageing and survival in orthodox seeds. Seed Sci. Technol. 9: 377-409.

FAO (Food and Agriculture Organization of the United Nations), Accessed December; 2016. Soils Portal, Management of Salt Affected Soils. Available from: http://www.fao.org/soils-portal/ soil-management/management-of-some-problem-soils/saltaffected-soils/more-information-on-salt-affected-soils/en. [Last accessed on 2016 Dec 20].

FAO (Food and Agriculture Organization of the United Nations). 2015. In: P. Gennari (Ed.), FAO Statistical Pocketbook 2015 World Food and Agriculture, FAO, Rome, p. 236.

Feyzi, M. 2003. Effect of irrigation water salinity on wheat yield. Soil Water Sci. 16: 215-221.

Francois, L. E., E. V. Maas, T. J. Donovan and V. L. Youngs. 1986. Effect of salinity on grain yield and quality, vegetative growth and germination of semi-dwarf and durum wheat. Agron. J. 78: $1053-1058$.

Hadas, A. 1977. Water uptake and germination of leguminous seeds in soils of changing matrix and osmotic water potential. J. Exp. Bot. 28: 977-985.

Houle, G., L. Morel, C. E. Reynolds and J. Siégel. 2001. The effect of salinity on different developmental stages of an endemic annual plant, Aster laurentianus (Asteraceae). Am. J. Bot. 88: 62-67.

Izadi, M. H., J. Rabbani, Y. Emam, M. Pessarakli and A. Tahmasebi. 2014. Effects of salinity stress on physiological performance of various wheat and barley cultivars. J. Plant Nutr. 37: 520-531.

Jeannette, S., R. Craig and J. P. Lynch. 2002. Salinity tolerance of Phaseolus species during germination and early seedling growth. Crop Sci. 42: 1584-1594.

Julkowska, M. M., H. C. J. Hoefsloot, S. Mol, R. Feron, G. J. de Boer, M. A. Haring and C. Testerink. 2014. Capturing Arabidopsis root architecture dynamics with root-fit reveals diversity in responses to salinity. Plant Physiol. 166: 1387-1402.

Maguire, J. D. 1962. Speed of germination-aid selection and evaluation for seedling emergence and vigor. Crop Sci. 2: 176-177.

Munns, R. 2002. Comparative physiology of salt and water stress. Plant Cell Environ. 25: 239-250.

Pakar, N., H. Pirasteh-Anosheh, Y. Emam and M. Pessarakli. 2016. Barley growth, yield, antioxidant enzymes and ions accumulation affected by PGRs under salinity stress. J. Plant Nutr. 39(10): 1372-1379.

Panuccio, M. R., S. E. Jacobsen, S. S. Akhtar and A. Muscolo. 2014. Effect of saline water on seed germination and early seedling growth of the halophyte quinoa. AoB Plants Open Access J. Plant Sci. 6(47): 1-18.

Parida, A. K. and A. B. Das. 2005. Salt tolerance and salinity effect on plants. Ecotoxicol. Environ. Safe. 60: 324-349.

Pazuki, A., M. Sedghi and F. Aflaki. 2013. Interaction of salinity and phytohormones on wheat photosynthetic traits and membrane stability. Agriculture. 59: 33-41.

Pessarakli, M. 2015. Effects of a bio-stimulant and salinity stress on growth and quality of ryegrass (Lolium prenne L.), An urban desert landscape and forage crop, for sustainable agriculture in arid regions. Int. J. Water Resour. Arid Environ. 4(2): 94-104.

Pessarakli, M., H. Maryam and A. Sheibanirad. 2015. Plant responses under environmental stress conditions. Adv. Plants Agric. Res. J. 2(6): 73.

Qu, X. X., Z. Y. Huang, J. M. Baskin and C. C. Baskin. 2008. Effect of temperature, light and salinity on seed germination and radicle growth of the geographically widespread halophyte shrub Halocnemum strobilaceum. Ann. Bot-London. 101: 293-299.

Sanchez, P. L., M. K. Chen, M. Pessarakli, H. J. Hill, M. A. Gore and M. A. Jenks. 2014. Effects of temperature and salinity on germination of non-pelleted and pelleted Guayule (Parthenium argentatum A. Gray) seeds. J. Ind. Crops Prod. 55: 90-96.

Scott, S. J., R. A. Jones and W. Williams. 1984. Review of data analysis methods for seed germination. Crop Sci. 24: 1192-1199.

Smedema, L. K. and K. Shiati. 2002. Irrigation and salinity: A perspective review of the salinity hazards of irrigation development in the arid zone. Irrigation Drainage Syst. 16: 161-174.

Zhang, H., L. J. Irving, C. McGill, C. Matthew, D. Zhou and P. Kemp. 2010. The effects of salinity and osmotic stress on barley germination rate: Sodium as an osmotic regulator. Ann. Bot-London. 106: 1027-1035. 